\title{
TOILING AND TILLING
} THE SOIL

RUMELY TRAOTOR CO. 


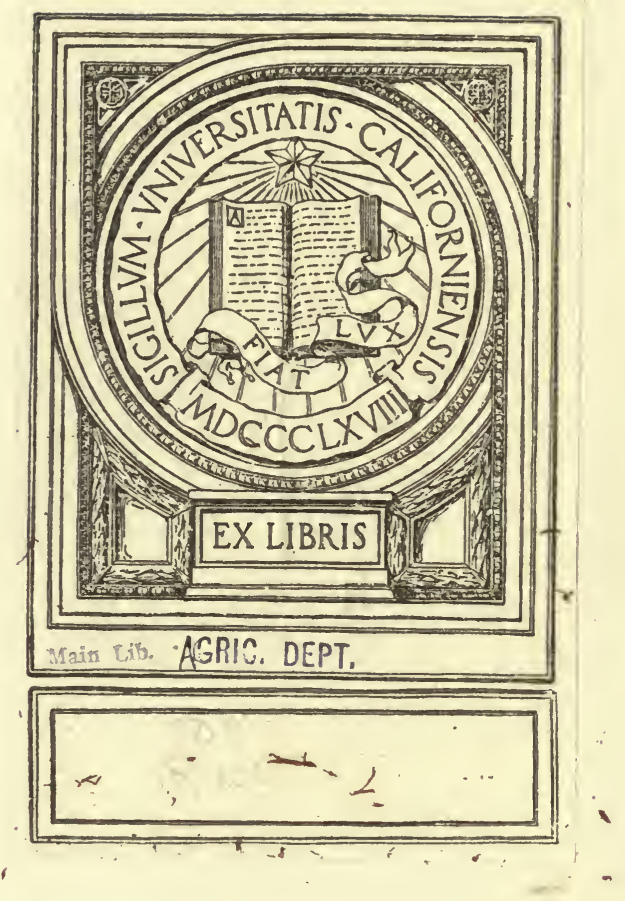






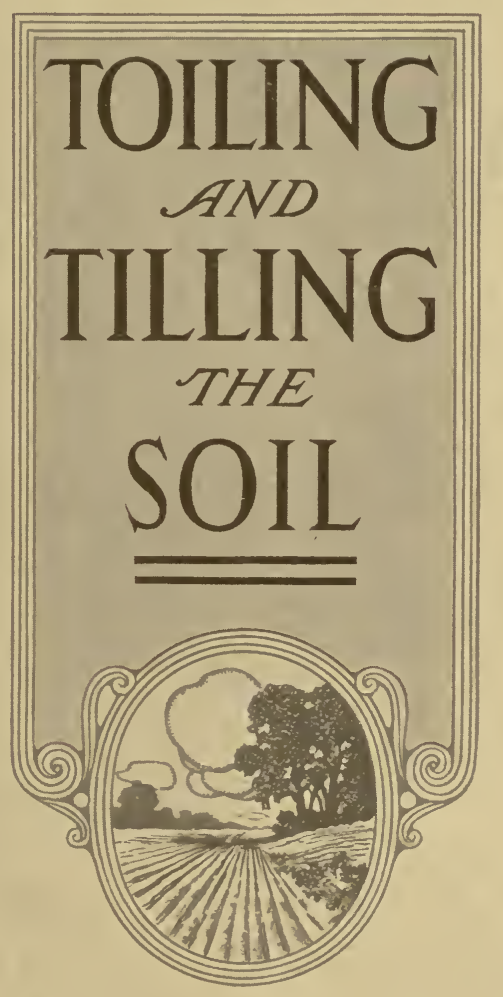


"4a

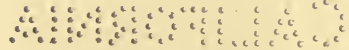


Digitized by the Internet Archive in 2008 with funding from Microsoft Corporation 


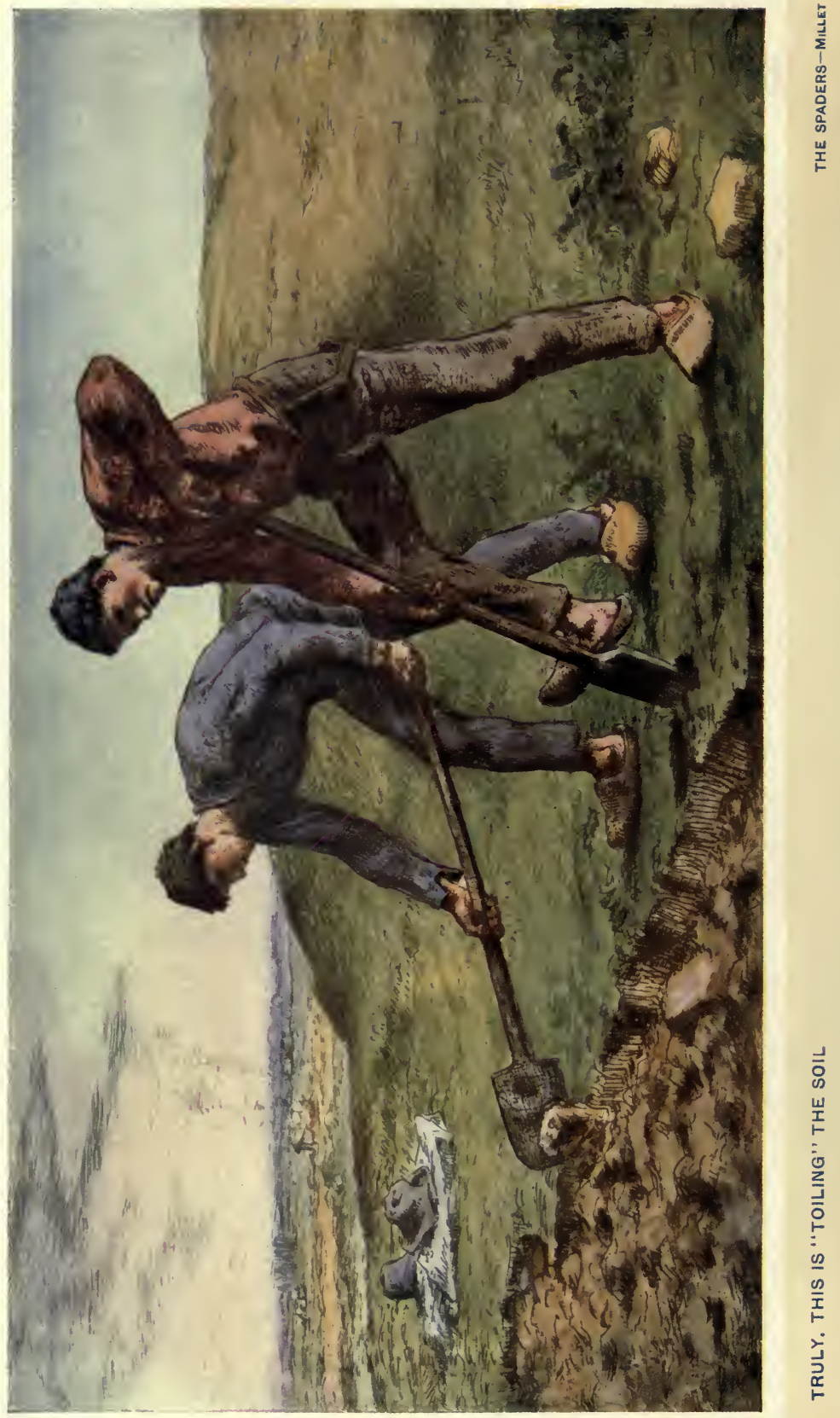




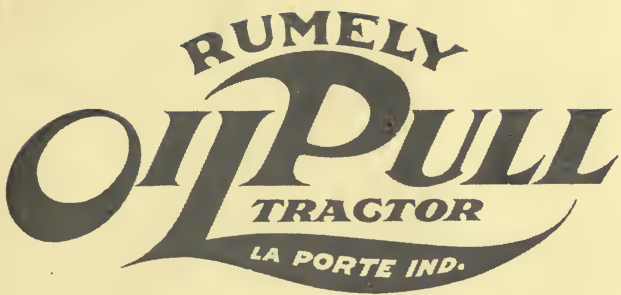

Copyright November, 1909, by Edward A. Rumely

Illustrations on pages 7 and 9 from stereograph

Copyright by

Underwood \& Underwood, New York

M. RUMELY COMPANY

Home Office and Works:

LA PORTE, INDIANA

BRANCHES :

Chicago, Illinois

212 South Canal Street

Denver, Colorado

Des Moines, Iowa

Fond du Lac, Wisconsin

Grand Forks, North Dakota

Indianapolis, Indiana

140 Capitol Avenue, So.

Kansas City, Missouri

1222 W. I Ith Street, Station A

Logansport, Indiana 500 High Street

Lincoln, Nebraska P. O. Box 482

Minneapolis, Minnesota 334 North First Street

St. Louis,

Toledo, I 412 Cherry Street

Wichita,

Missouri

Ohio

Kansas

CANADA

Winnipeg, Manitoba Calgary, P. O. Box 1794

roth Avenue and

Regina, Saskatchewan

Saskatoon, Saskatchewan 
Engraved and Printed by the Franklin Company of Chicago 


\section{O Put}

$\mathrm{M}$ AN made his first step toward civilization when he took a crooked stick and began to till the soil, using first the force of his own muscles. Later he learned to apply the power of the animal to the work. Upon cultivating the soil, he became master of the plants and shaped them to serve his purposes. With the plow the savage life of the hunter and the nomad life of the herder gave way to that settled agriculture that now yields our food supply and upon which rests our modern civilization.

Strangely enough, this work of plowing with which man began his systematic labor remains today still his severest toil. For man, as well as animals on the farm, the dusty and monotonous work of plowing is the hardest drudgery. Think of the power required to pull a plow only the distance across the room, and then of the eight miles of furrow travel in every acre of land. To plow a square mile one man and two or three horses must walk 5,200 miles each. It is easier and the distance less to walk around the earth at the equator than to follow a plow turning a tract of five square miles. To plow three townships the plowman must walk as far as from the earth to the moon and back again and sixty thousand miles farther. Ten horse power hours are needed to turn an acre of land, and to plow one half the area of the United States nine billion four hundred and fiftyfour million seven hundred and thirty-six thousand $(9,454,736,000)$ horse power hours are required.

In the main, power is required for three great human needs.

First. To changing the shape of materials, as grinding of grains, spinning, weaving, and the working of metals and wood in factories.

Second. For transporting men and materials from place to place upon the earth. In wagons, steamboats, on railroad trains, automobiles and motor trucks.

Third. In tilling the soil, and in this field the toil of turning once each year by the plow the face of the whole earth consumes more power than any other single human need.

This plowing task-man's earliest and still his greatest need for power-until yesterday has been performed almost exclusively by animals. Today, only one acre in twenty thousand is plowed by mechanical power, and this not without reason.

The world's most efficient. machine is still the human and animal muscle, which in all the perfection to which it has been developed in the countless 


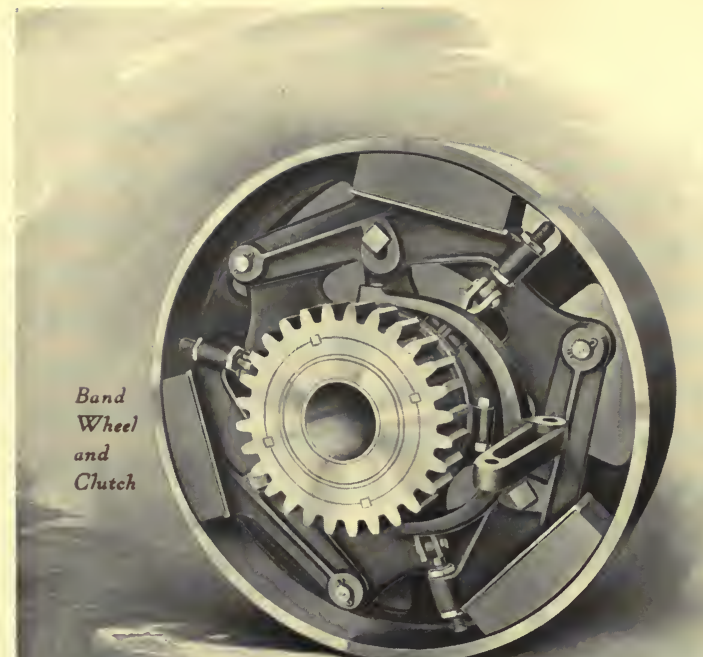

ages gone is able to deliver only from forty to fifty per cent of its thermal energy in pull.

The horse, however, has certain disadvantages - its body must be fed and kept warm when idle, during fatigue periods, at night and through the long cold winters. The engine when not in use consumes no fuel, and can be set aside in the fall to await the next spring's work, without attention. If properly oiled, the engine does not deteriorate when not in use, while animals grow old whether they are working or not and are subject to disease and premature death.

Horses must be fed and watered every day. Oil, used as a fuel, is cheaper than oats. One man can control four or five horses at work, while with an engine the power of one hundred horses can be centered in the hand of a single operator.

The time of plowing is short and requires quick work. Horses cannot be worked more than ten hours per day. They must be rested and fed, while the engine with a headlight can be operated twenty-four hours per day.

These advantages, together with the fact that the thermal efficiency of the oipure almost equals that of nature's great prime mover, the horse, enable us to compete with the animal and to do its work for from one-half to one-third the former cost.

James Watt perfected his steam engine in ${ }^{7} 76_{5}$. We must think back but 140 odd years to realize what a revolution he brought about-there is the railroad forming a regular network over the face of the country, connecting cities, states and nations, facilitating transportation of products from city to city, state to state and nation to nation. There is the modern city with its factories that furnish employment and living for millions of workers. The steam engine has changed our lives from their very foundations up and in those countries where it is used it has increased the population itself five and six fold.

Before Stephenson, transportation was carried on by the use of horses on country roads. He harnessed steam and made it do 


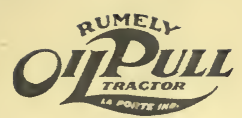

that work, and a network of railroads has grown that today it nearly encircles the earth.

Robert Fulton made the steam engine available for water transportation. Today we pass from New York to Europe in five days, and the nations have been linked together and unified in thought by steam-driven water commerce.

Oil is the most abundant and easily portable of all liquid fuels. Man's greatest power is that of turning the face of the whole earth once each year by the plow. The building of an oilburning engine to do the work of plowing in this, the rooth year after the first steamboat, is a feat that will mean as much, possibly more than the inventions of Stephenson and Fulton.

\section{THE WORLD'S WHEAT SUPPLY}

James J. Hill and James A. Patten have called attention to the fact that we are pressing on the limits of wheat production, and that unless the undeveloped districts of the United States, the new lands of Canada, the Argentine and Russia are opened rapidly, an actual dearth of wheat-that noblest of all foodstuffsis imminent. Wherever cattle are kept on a farm. the wheatproducing area is curtailed.

Nitrate fertilizers manufactured from the air by water power, together with the revolution in plowing, which opun will effect will enable us to devote virgin areas exclusively year after year to the production of wheat. With ojpur these new lands can be opened very profitably and ten times as rapidly as at present.

OMy $\mathbb{P}_{\text {yur }}$ cuts the cost of producing a bushel of wheat in Canada, the Dakotas or Argentine ten cents, adding that much to the pioneer farmer's profit.

Owing to the drouth that impaired the hay crop in the Argentine this year, there was a scarcity of horses for the work of plowing. The development of the Argentine and in many districts even the acreage already under cultivation, was curtailed. 


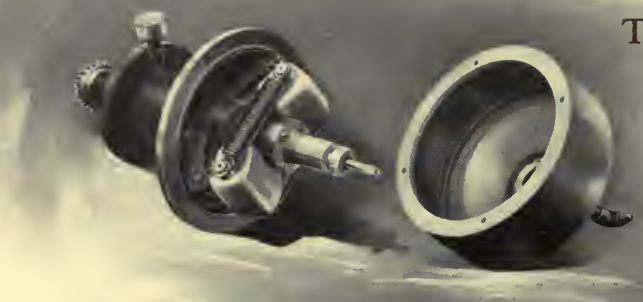

Automatic

Governor

\section{THE KEROSENE LAMP} TELLS THE STORY

Like the boiling teakettle with James Watt, the plain kerosene lamp revealed the secret of perfect combustion to John A. Secor.

A lamp burner when turned too high furnishes too much oil, which results in free carbon and a sooty lamp chimney. If the lamp is turned too low the combustion becomes incomplete, and the lamp throws off poisonous gases of an unpleasant odor. Good illumination is dependent on careful adjustment of the wick by means of the thumb wheel. This must be done several times each
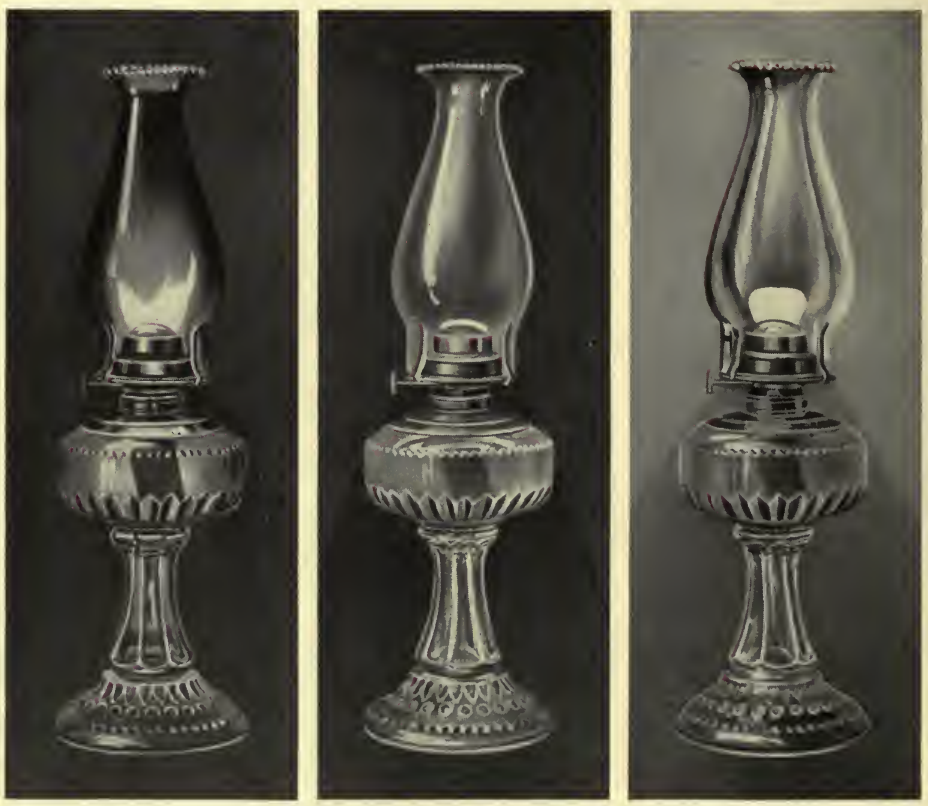


\section{OP}

evening, as the temperature of the air and other conditions change. When the wick is just at the proper point there is no odor and

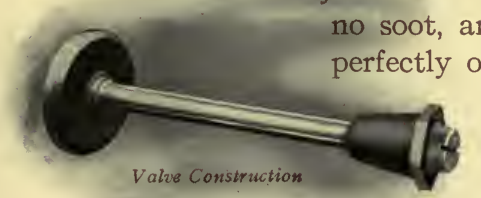
no soot, and a brilliant soft light shows how perfectly oil can burn. In other words, good illumination and good combustion are dependent on accurate adjustment in the supply of fuel and air.

The difficulty in an engine is that this adjustment of the oil and air to be exploded in the cylinder must vary from moment to moment, from minute to minute, with the increasing or decreasing load and other changes in atmospheric conditions. The human hand is not quick enough, not deft enough, to regulate the fuel supply of an engine. Regulation must be effected positively and automatically. Those fractions of a few drops of oil must be weighed out with a precision of the finest chemist's scales.

The statement that the right quantity of fuel in correct proportions and in perfect mixture with the air, exploded at the proper phase, must result in a successful oil engine, seems simple. Only the many failures and the millions of dollars in money that have been lost in futile attempts to construct a practical oil engine will show the difficulty of the problem and the achievement of the Secor system in the opipuse.

To secure the best results in an oil-burning internal combustion engine, water must be used. The quantity of water must vary with the load. If too much is introduced, the cylinder is flooded and the engine killed; if too little, the desired effect is not obtained.

At the moment of the explosion the water is evaporated and disassociated into its

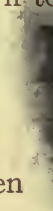
elements of hydrogen and oxygen. This free or nascent oxygen attaches itself to any free carbon and exerts a scouring effect in the cylinder. As the piston stroke advances and the temperature drops, hydrogen again turns to water and liberates its heat, thus keeping up the pressure. Hence, the Secor system shows a very high $\mathrm{M}$. E. P. with small initial pressure. This

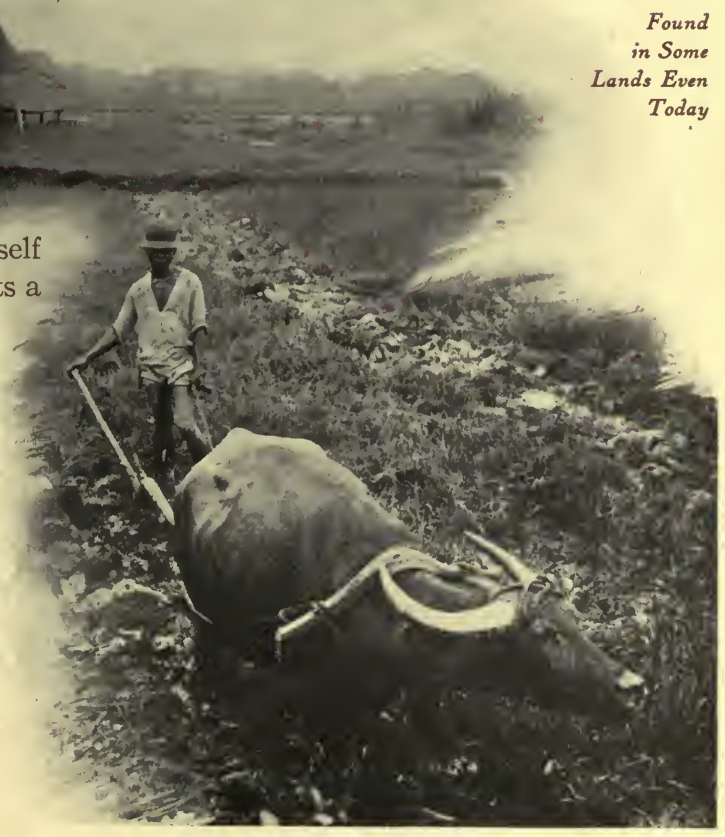

Found in Some

Today 


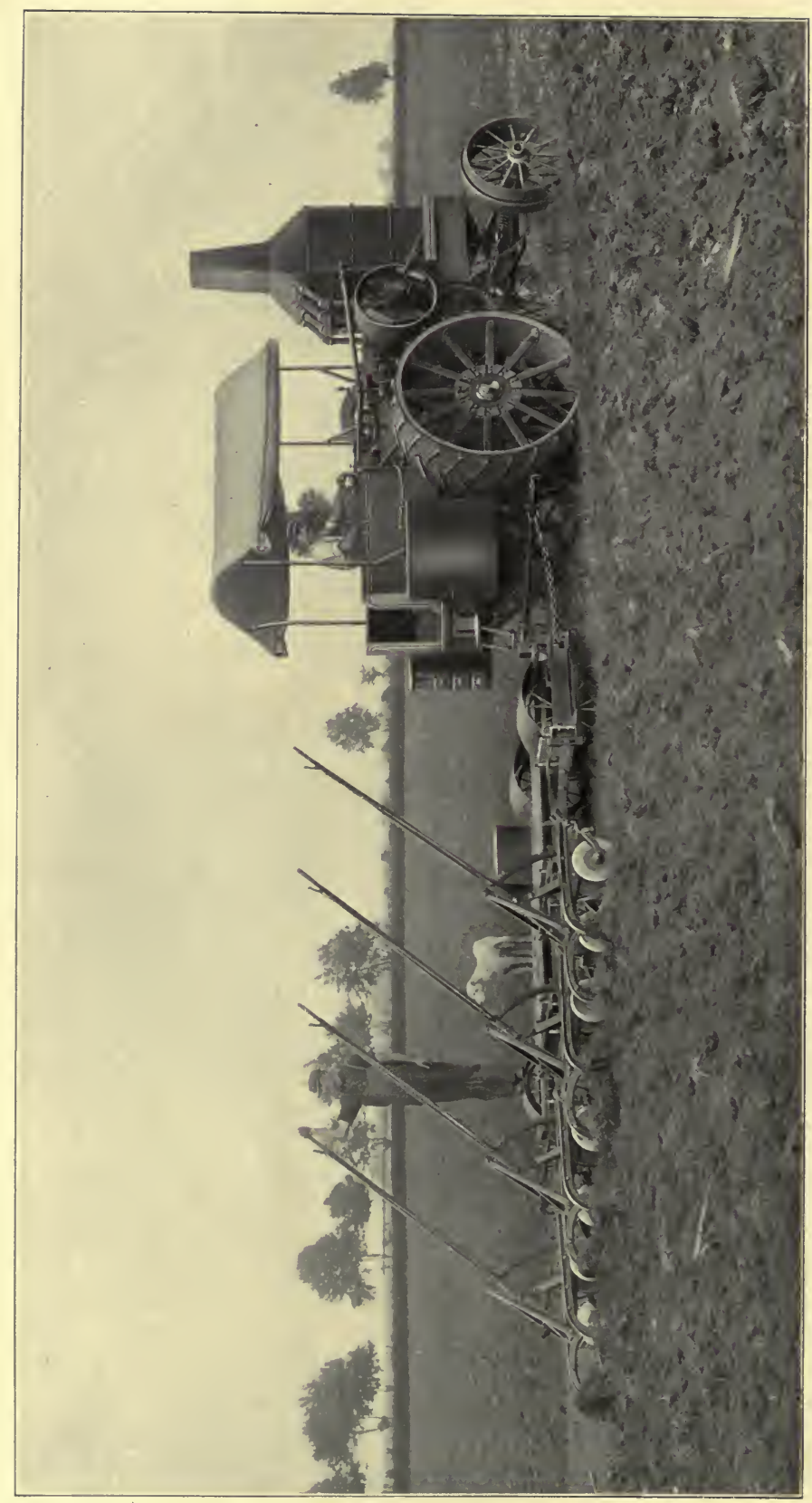

(1)

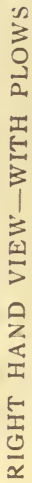




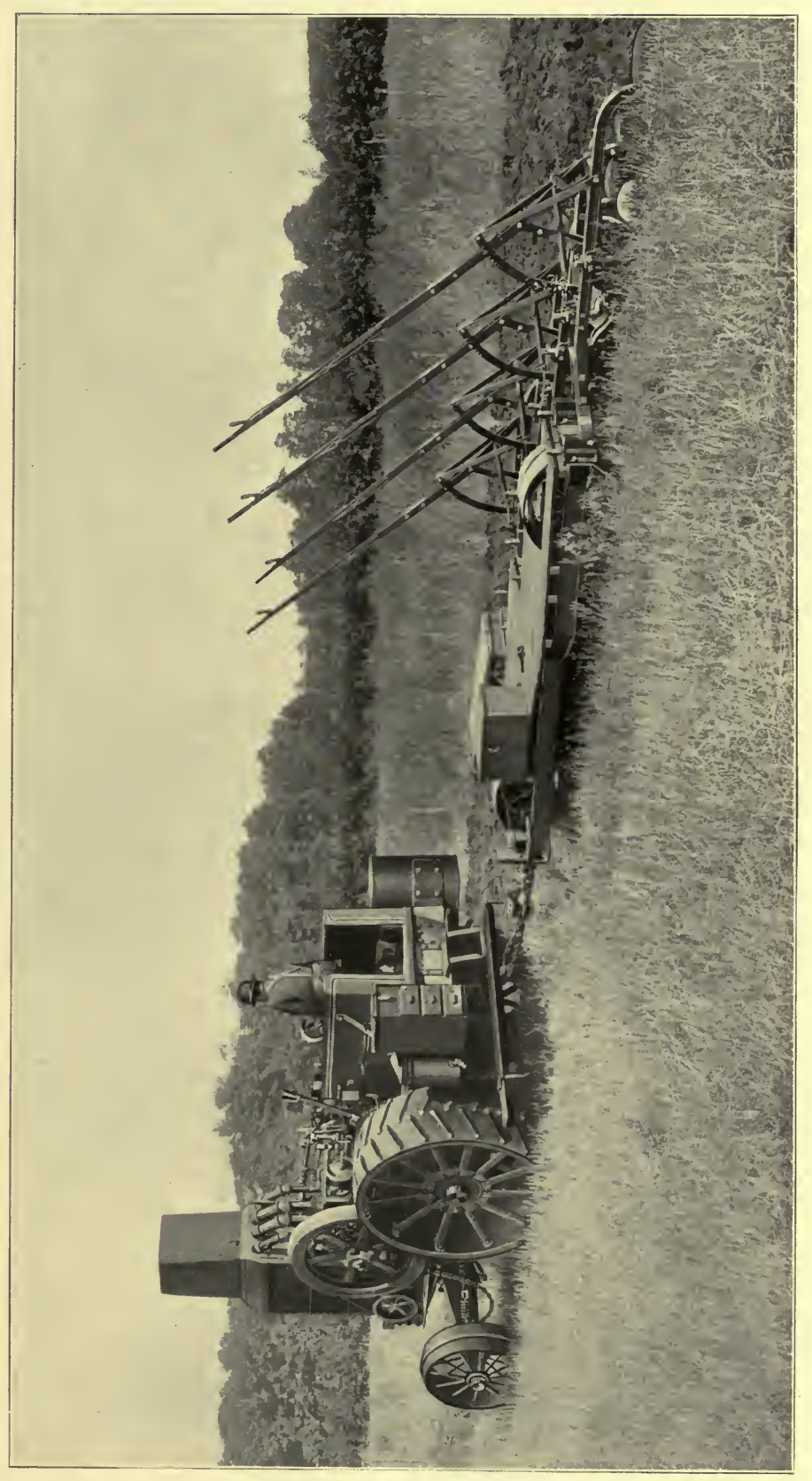

舟

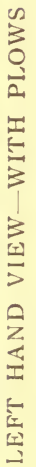




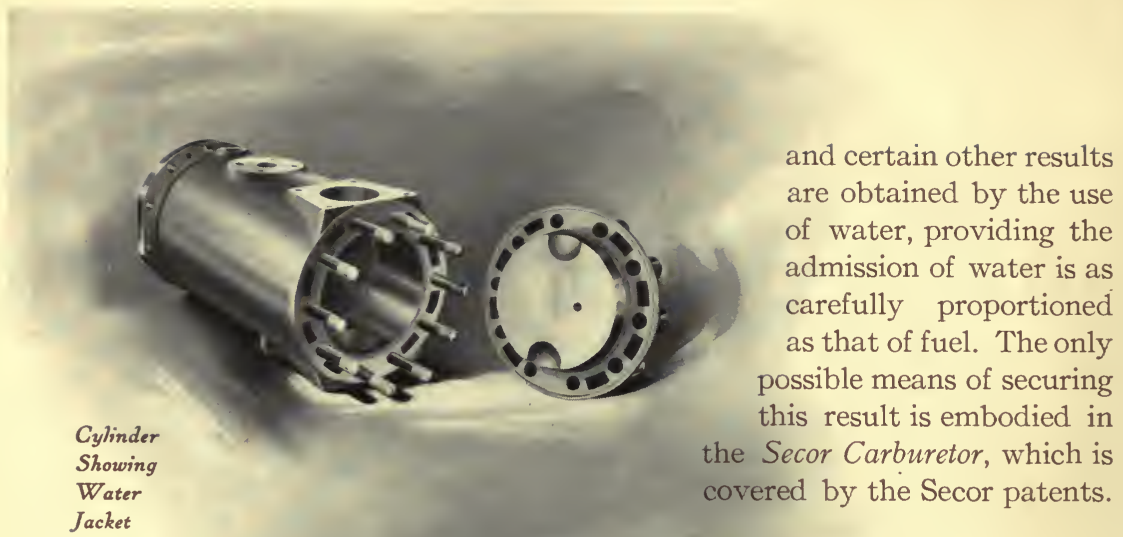

\section{KEROSENE FOR FUEL}

Kerosene is the most concentrated fuel obtainable at any price. It is the most universally distributed, for wherever man is with matches, at every country store, kerosene can be had, while gasoline is on sale only at certain points. Kerosene is not dangerous, does not evaporate, and consequently does not involve the risk of explosion that is always present with gasoline. Even the insurance companies recognize this by permitting the use of a Secor kerosene engine in New York City without increase of insurance rates in buildings where gasoline engines are absolutely prohibited. Kerosene is uniform in quality, while gasoline is subject to great variation. Gallon for gallon kerosene contains about eighteen per cent more heat than gasoline, while it costs very much less. Three per cent of the crude oil of the world refines into gasoline, and sixty per cent into kerosene and the lower grade oils. In consequence, the price of gasoline is constantly increasing, while that of kerosene tends to decline. At the present time the refineries are working "from hand to mouth" with gasoline, while they hold millions of barrels of kerosene in storage for want of a market. Fifteen years ago gasoline sold at wholesale at two cents per gallon, while kerosene brought twelve cents. Today, in Indiana, the wholesale price of kerosene ranges from five to eight cents, while gasoline sells at twelve and thirteen cents, with a tendency to still further increase in price.

oline is not an ordinary internal combustion engine that occasionally can burn a little kerosene when all conditions are particularly favorable. Kerosene and the cheaper fuel oils, which 


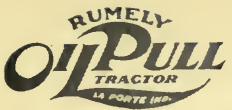

can be secured at the refineries at prices as low as $I \frac{1}{2} \mathrm{c}$ per gallon are its bread-its daily food. It burns kerosene at maximum load as well as at no load. Temperature and atmospheric conditions do not affect its operation.

This feature regarding fuel costs and the fact that oiputu burns kerosene should be borne in mind by those about to purchase an engine, since three years hence the price of gasoline will be much higher.

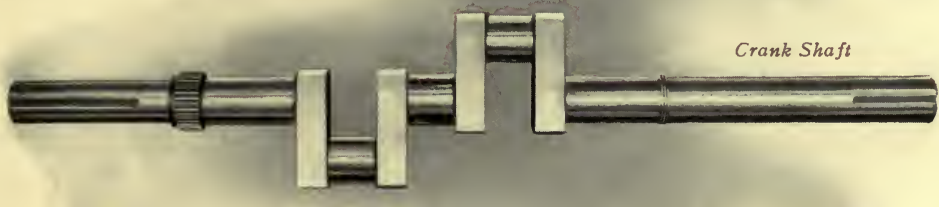

\section{COST PER WORKING DAY}

Engine, cost $\$ 2,800$, divided by r,ooo working days..... $\$ 2.80$

Freight and incidentals ....................... .50

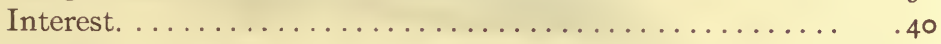

60 gallons kerosene at $6{ }_{3}^{2} \mathrm{c}$ per gallon. .............. 4.00

Lubrication .............................. .30

Labor-engineer at $\$ 3.5^{\circ}$

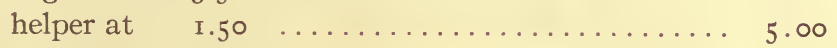

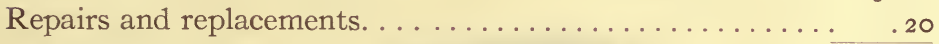

Total cost of plowing (I day) twenty acres......... I 3.20

Total cost of plowing one acre ................ .66

This cost will vary somewhat in different localities. In light loamy soil the oil consumption would be less, while in the tough gumbos more power, and consequently more oil, is required. The cost of labor varies considerably. The calculation is based upon a working day of ten hours. If the engine is used more than that number of hours in one day, interest and other charges are correspondingly lower. If fuel or gas oil, which can be obtained at from two to three cents per gallon, is used in place of kerosene, the fuel cost is much less. When well handled, a larger acreage can be turned.

\section{GENERAL CONSTRUCTION}

OPue is built on a foundation of I $2^{\prime \prime}$ I-beams, which weigh $3 \mathrm{I}^{\frac{1}{2}}$ pounds per lineal foot. These I-beams are securely riveted together and thus

Suitable Only for Small Plots 


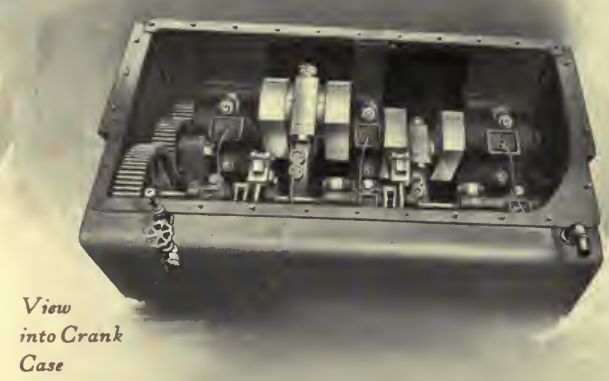

form one solid block, like the oak sills in a well constructed house. There are no bolts to work loose, and every part of the engine is held securely in perfect alignment. On these beams is solidly mounted the crank case which contains the engine and the other essential parts.

The strains on a plowing engine are enormous. It must stand the work, for breakdowns which cause trouble and delays are dangerous and costly. The design of the oipure puts every pound of metal used where it is needed to meet the strains, and the metals used are of the finest cast iron, steel and semi-steel of our own formula.

\section{ACCESSIBILITY}

The lubrication of all bearings is well provided for. The governor itself runs in a bath of oil that needs to be renewed but once in three or four months. In addition to the most complete possible protection from dust, we have combined accessibility. By simply removing the cover of our crank case all the vital parts of our engine are exposed to full view and are within easy reach of the operator. The cylinder head has no spark plug or other device attached to it, so that it can be removed in two minutes. Every other part of the engine can be reached easily and quickly.

The oipure can carry in its tanks fuel enough for a ten hours' run. Both the oil and water supply can be increased to provide for continuous operation over a longer period without taking on fuel.

Our engine is so built that it radiates the heat without evaporating water. Either water or oil can be used as a medium for carrying heat from the cylinder wall to the cooler. In the construction of this cooler we have followed new scientific principles, thus accomplishing the desired result with the minimum amount of metal and liquid. 


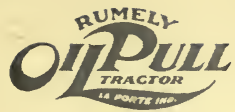

CRANK CASE AND SHAFT

The crank case is cast in one piece of a special mixture of semi-steel of unusual strength. It is so proportioned that vibration will not affect it. The crank shaft has an intermediate bearing or pillow block, which prevents vibration and crystallization.

This crank case is hermetically sealed with a sheet iron lid that shuts out all dust. It contains ten gallons of lubricating oil, which is forced by splash and a force pump over all bearings, as well as in the cylinders and all other moving parts. This oil is in constant circulation and is kept absolutely clean by passing through a wool filter once every ten minutes.

Our crank shaft is of the highest quality of steel and exceeds in its composition the requirements of the United States naval specifications.

\section{THE SECOR CARBURETOR}

The Secor carburetor is as simple as an anvil and has no parts to wear, break or get out of order. It is carefully adjusted at the factory and that adjustment is then fixed for all time. Where other engines depend on daily adjustment and the constant vigilance of the operator to maintain efficiency by hand regulation, the Secor carburetor secures uniformly good results by automatic control, which is not only more reliable than the human hand, but also much more sensitive and accurate. This method controls not only the intake of oil, but regulates

The Acme in the Use of AnimalPower 


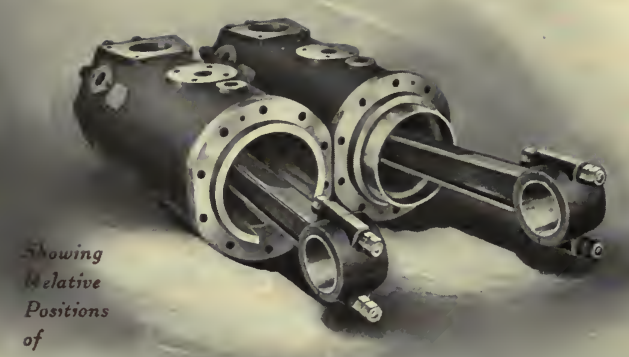

Cylinders also the quantity and proportion of water in accordance with the needs of the engine.

The valve plate in the Secor carburetor is provided with one or more mathematically proportioned air passages and is connected with the governor in such a manner that it is absolutely positive in its workings. In this manner an unfailing link is established between the operation of the engine, its loads, and the fuel supply and every variation of the belt and draw bar pull instantaneously makes itself felt in the fuel mixture and the next explosion is proportioned to meet the new need. This is a vital element in the Secor principle.

The Secor principle of combustion which is followed out in olpure is adapted for use in automobiles, railway locomotives, truck wagons, motor street cars, stationary engines of all designs, as well as marine engines.

Our governor is simple and at the same time extremely sensitive. It operates on the throttling principle, by which greater uniformity can be secured, and the vibration and shock of the irregular and violent explosions of the "hit and miss" engine avoided. The governor is positively actuated by gears and is

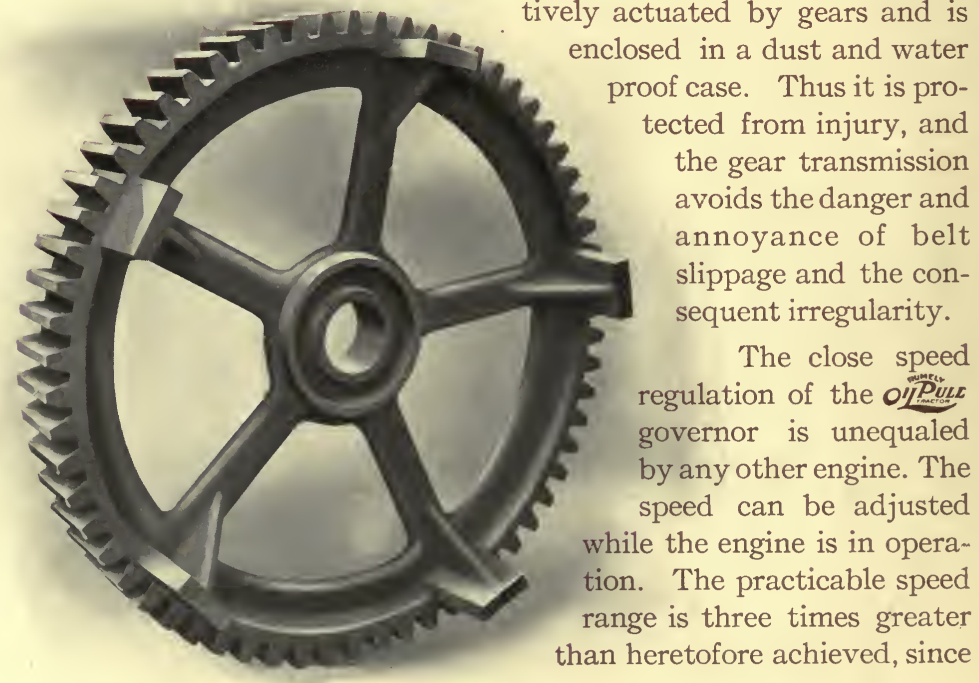
tected from injury, and the gear transmission avoids the danger and annoyance of belt slippage and the consequent irregularity.

The close speed regulation of the opure governor is unequaled by any other engine. The speed can be adjusted while the engine is in operation. The practicable speed range is three times greater than heretofore achieved, since 


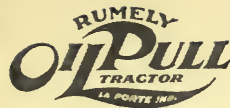

the engine can be adjusted from 250 to 450 R. P. M. When the entire load is thrown off the engine, as when stopping a thresher or releasing the draw bar pull, the readjustment of all working mechanism is automatic, positive and instantaneous.

The drive wheels are built of steel and reinforced with angle irons at the edges to prevent bending. The spokes are steel with double forged heads to resist vibration. The hub is massive. Our lugs have been carefully shaped and so pitched as to be self-cleaning. This is important. An engine must not only generate power, but it must grip itself to the earth with its steel teeth broadly and firmly, so as to avoid loss of power by slippage.

\section{GEARING}

The M. Rumely Company has built steam traction engines by the thousands. We have studied the problem of power transmission through gearing from twenty-five years of actual experience. The reputation of our steam engines for durability and strength as pullers shows how well we have solved these problems. From this priceless fund of experience that is stored in our organization we have drawn in designing our opure truck. The pitch and shape of the gear teeth are so chosen as to get the greatest strength with resistance to wear with the smallest possible friction loss. The metal itself is of semi-steel that has a tendency to wear smooth. Accurate tests showed a truck efficiency, including power spent in transporting the engine itself, of sixty-five per cent, a record unequaled under similar conditions by any engine of its size.

There is no idle gearing in operation at any time. When the engine is used for threshing, under belt power, it can move itself forward or backward without stopping the belt.

Oil $\mathcal{P}_{u} \pi$

the Dawn of

Successful

Mechanical

Plowing

The engine is provided with two friction clutches, one for use in threshing and the other for starting and stopping the movements of the truck. These clutches are provided with three and four shoes respectively. They are handled easily by a platform lever with little exertion on the part of the operator. The toggle bolts are adjustable to take up the wear of the wood blocks. The front wheels pivot on a ball and socket bearing, by which they can adjust themselves to inequalities of the ground without imparting their movements to the engine as a whole. 


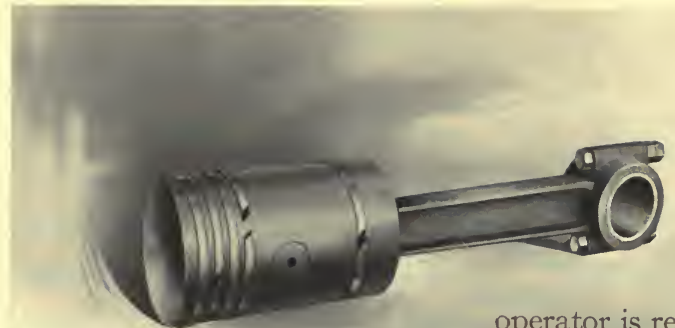

\section{OPERATION}

operator is required in other types of engines;

hence, any intelligent farm hand can learn in three hours to operate successfully the opPur . When plowing, the

Piston and Connecting Rod operator has only to guide the engine. Every other part operates automatically.

Our governor system is of the "make and break" type, which operates with a low tension current which on that account is not liable to short-circuit. We provide a double supply of current in a set of dry batteries and in a magneto that is positively actuated by gearing. This magneto is covered with a brass shield to exclude oil, dust and water.

\section{ADAPTABILITY}

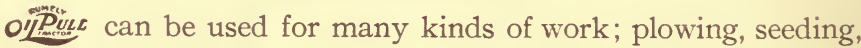
harvesting, cultivating, threshing, clover hulling, for hauling grain to the market, for pumping water on the farm or at the irrigation plant, for railroad building, lumber hauling, for bringing ores and other heavy materials to railway points. In addition to serving these general purposes, it will be found indispensable for special needs, wherever either traction or belt power is required.

\section{RELIABILITY}

Cheap shoes and cheap clothing wear out soon, while the better quality not only wears longer, but gives better satisfaction while in use. The same is true of every kind of machinery. Cheap machines can be built for short lived, troublesome service. The Rumely name has always stood for quality output. We believe that engine buyers prefer to pay the additional price required for high class machinery. The selling of repairs is profitable. We know it; but while our customer is waiting for a repair on which we could make a few dollars of profit, he will be losing hundreds of dollars by the loss of time. Consequently, we have designed and built an engine every part of which is intended never to break. The o pusu costs more money to buy, but less to operate.

To those interested in the problem of Mechanical Plowing, which, during the next ten years, will become a factor of paramount importance in the agricultural field, we direct attention to the Information Blank attached. 

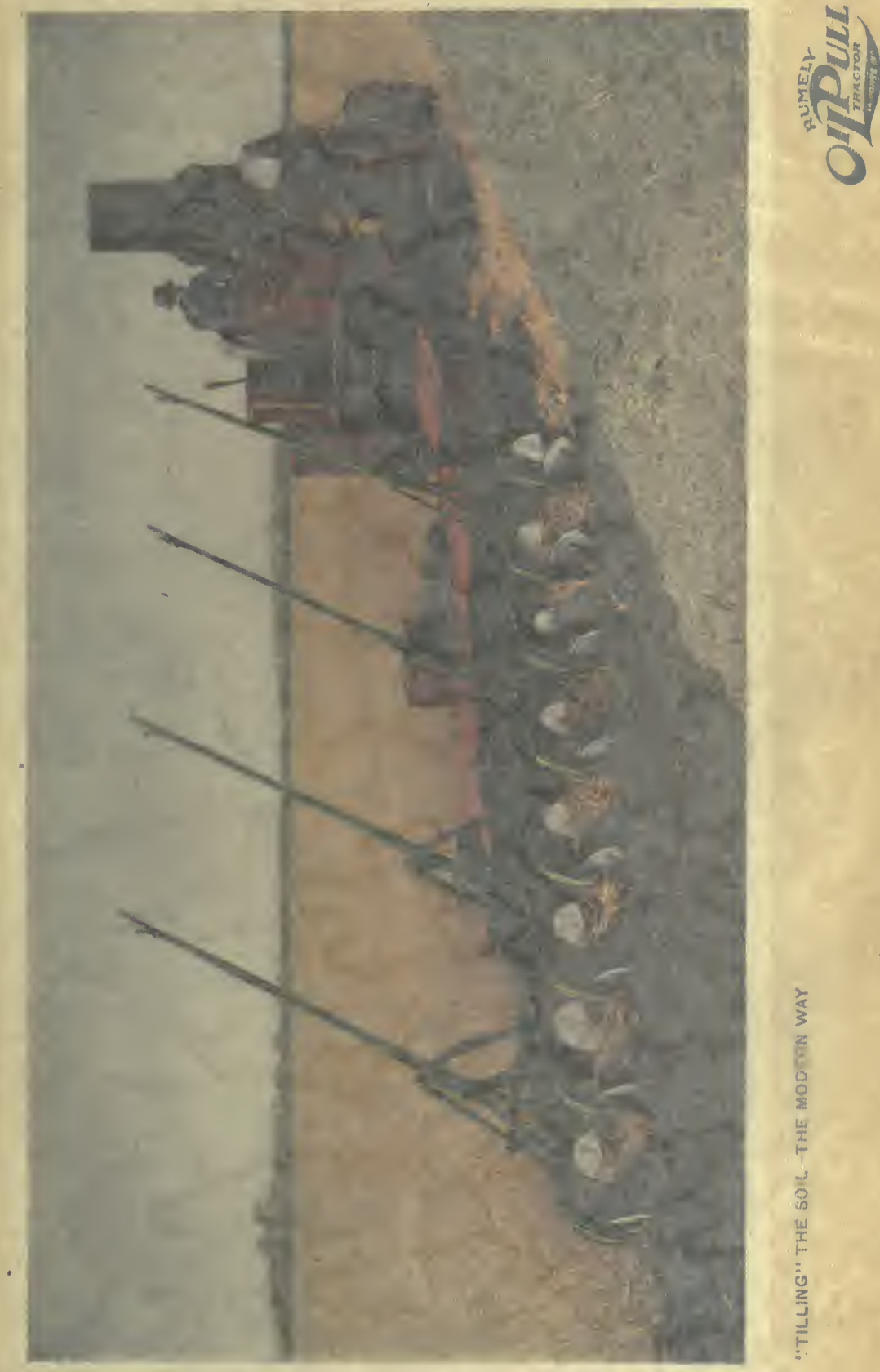

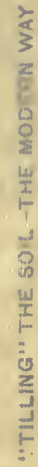




\section{OPERATION}

The governor and the Secor carburetor do the work for which a skilled. proutor e required in other types of engines:

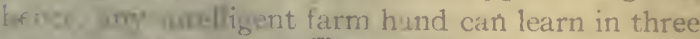

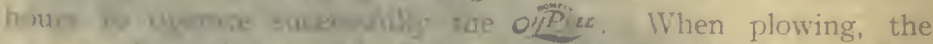

Piston and Cownecting Rod

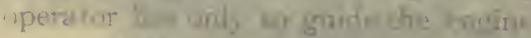
antumatiofis:

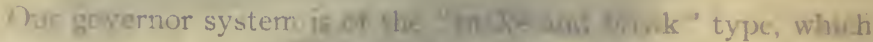
operetes with a low tention current sovek on wet account is not

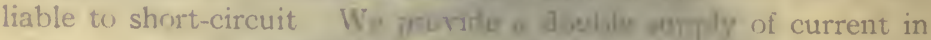

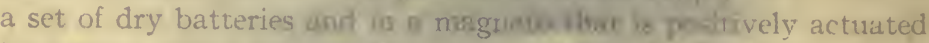
by gearing. This marneto is covered with $x$ brate slield to exclude oil, dust and wster

\section{ADAPTABILITY}

oppize can be used for many hurds of work: plowing moblines harvesting, cultivating, threshing, clover hulling, for hasiling gnwn to the masket, for pumping water on the farm ir at th- oryeam plant, for railroad fralding, lumber hauling, for bringing ore wot other heavy materials to railway foints In adution to servisy these general purposes, it will be found indispensible for sonctal needs, wherever either traction or belt power is required.

\section{RELIABILITY}

Cheap shoes and cheap clothing weur nut soon, while the better quality not only wears longer, liut gives better satisfaction while in use. The same is truc of every kind of machinery. Cheap machines can be built for short lived, troublesome service The Rumely name has always stood iur quility output. We believe that engine buyers prefer to pay the additional price required for high class machinery the selling of repairs is profitable We know it; but while our customer is waiting for a repair on which we could make a tew drillars of profit, he will be losing hundreds of dollars by the loss of time. Consequenty, we have designed and built an engine evers purt of which is intendel never to break. The ojpun costs more money to buy, but less to openate.

To those interested in the problem of Merlatical Plowing, which, during the next ten knirs, will beonme $\mathrm{x}$. Factor of paramount importance in the asricultural field, we direer attention to the Information Blank attoched. 

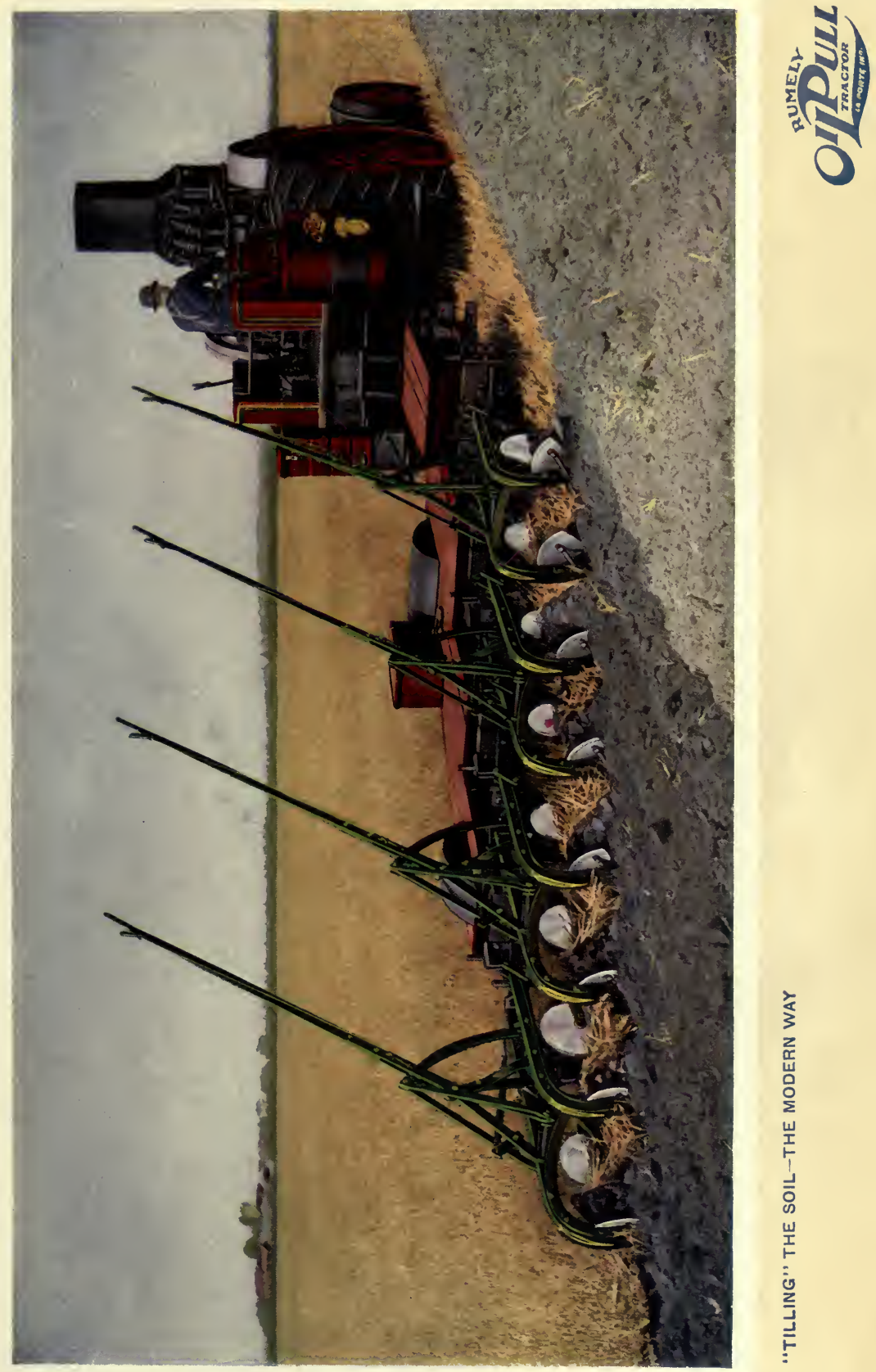

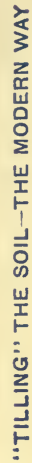



ECHANICAL POWER will supplant the horse to a rapidly increasing extent for the work of plowing. We have organized a clearing-house of information on the problems of traction plowing. Those interested in obtaining information, or in making suggestions regarding tractors, gang plows, or the operation of either, should fill out and send in this plank.

Have you any suggestions regarding special plowing engines of traction type required for your particular district?

What information can we gine you regarding mechanical plows and tractors that will be helpful to you?

Do you want detailed information regarding the including specifications, oil consumption, etc.?

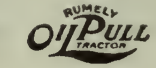

Have you ever operated a steam plowing outfit?

How much land do you plow?

Where is it situated?

How much of it is virgin prairie?

Do you intend to plow for others?

What is the price of horse plowing per acre?

The cost of coal per ton Of gasoline per gallon in barrels of kerosene per gallon in barrels.

of fuel oil per gallon in barrels.

Do you care to have our regular bulletins on threshing clover hulling steam threshing engines and steam plowing engines_? If so, check those desired.

Name

\section{Address}

City

County. State

I am deeply interested in the theory of mechanical plowing, and have organized all information available up to the present time. I will cheerfully give anyone interested access to these data, and in return, invite others to tabulate in our bureau any pertinent facts that would be generally helpful. 


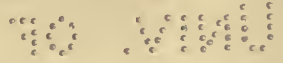

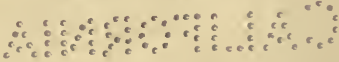

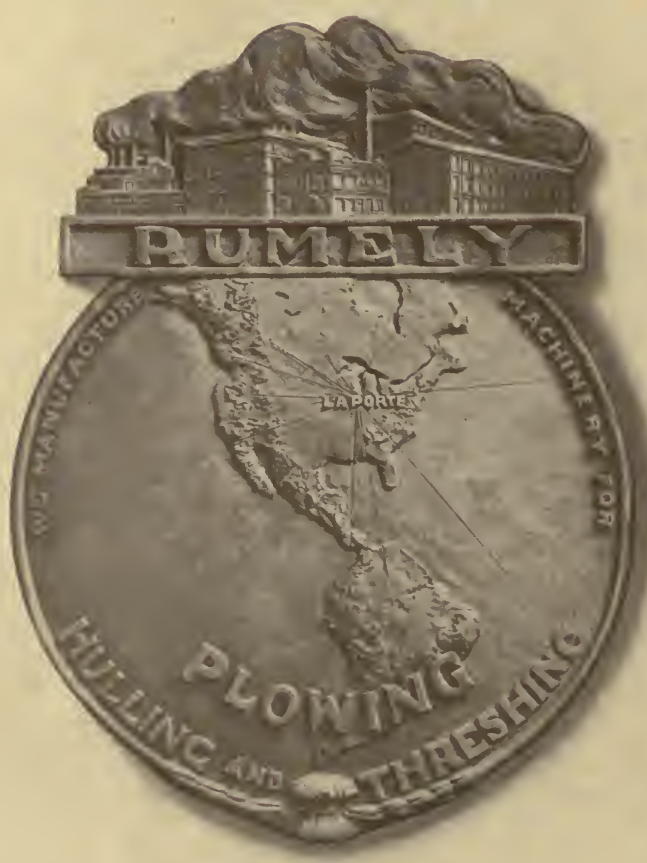





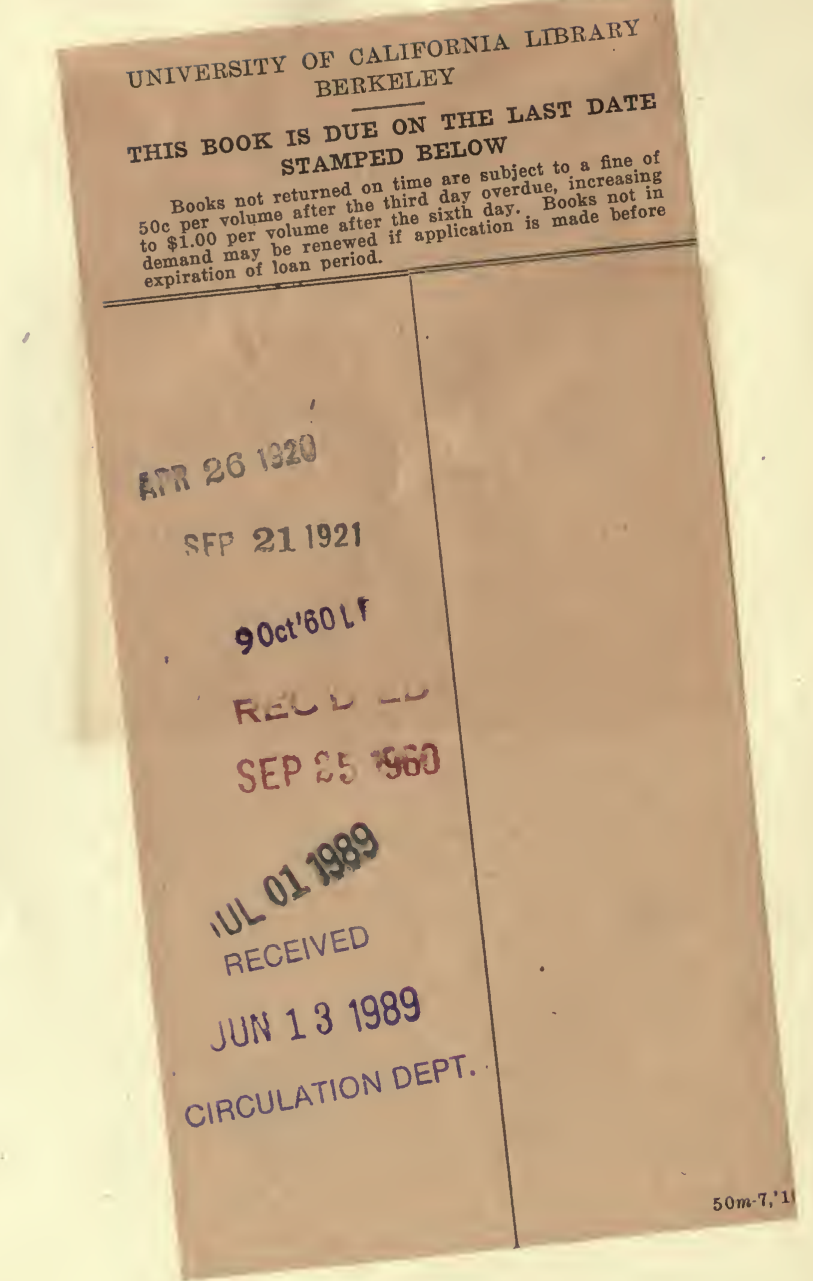


YD 025i

\section{U.C. BERKELEY LIBRARIES \\ C050915601}


